\title{
Effects of the Stage of Maturity of Merremia emarginata on Initiating Formation of Phytobezoars in Sheep in North Kordofan, Sudan
}

\author{
Musa Ahmed Musa Tibin ${ }^{1}$, Jumaa Barram Jadalla ${ }^{2 *}$, Yahia Ibrahim Mohammed Abutaba ${ }^{3}$, \\ Idris Adam Idris Abdalla ${ }^{2}$
}

${ }^{1}$ Department of Animal production and range Sciences, Faculty Natural Resources and Environmental Studies University of Peace, Alfula, Sudan ${ }^{2}$ Department of Animal production, Faculty Natural Resources and Environmental Studies University of Kordofan, Elobeid, Sudan

${ }^{2,3}$ Department of Forestry and Range science, Faculty Natural Resources and Environmental Studies University of Kordofan, Elobeid, Sudan

\begin{tabular}{l}
\hline A R T I C L E I N F O \\
Research Article \\
Received 21 November 2016 \\
Accepted 18 February 2017 \\
\hline
\end{tabular}

Keywords:

Rangelands

Harmful plants

Phytobezoars

Sheep nutrition

\begin{tabular}{l}
${ }^{*}$ Corresponding Author: \\
\hline E-mail: jumaaaringola2000@gmail.com
\end{tabular}

\begin{abstract}
A B S T R A C T
Thirty castrated rams of Sudanese Desert sheep breed, Hammari ecotype at 1.5-2 years were divided into five groups each with six animals. The animals were weighed prior commencement of the trial $(30 \pm 0.500 \mathrm{~kg})$ and once every week for ninety days. They were vaccinated against diseases endemic to the study area, drenched with a broad spectrum anthelementic and ear-tagged to facilitate identification during treatments. The rams were individually penned provided with drinking and feeding troughs. Rumen liquor was taken for in vitro dry matter and organic matter digestibility. During the trial period, animals were diagnosed by palpation for phytobezoars. At the end of the experiment rams were slaughtered, the site of formation of ball-shaped bodies determined, size and weight were also determined. Data was analyzed via analysis of variance. The results indicated increased feed intake for the group that was on a ration free of Merremia emarginata and those consumed rations with the plant biomass at vegetative growth and at flowering stages. At early and late maturity stages, feed intake decreased and phytobezoars were formed. The bezoars differed in weight and size, where larger and heavier ones were retained from the rumen, medium irregular ones from omasum and small bezoars from the reticulum. It was concluded that $M$ emarginata biomass could initiate phytobezoars' formation at seed formation stage or when it reached late maturity stage. Palpation showed presence of bezoars after continuous ingestion of feed containing the plant biomass. It was recommended that more studies be conducted to determine the minimal amount of the biomass under study to initiate phytobezoars' formation.
\end{abstract}

DOI: https://doi.org/10.24925/turjaf.v5i8.841-845.1086

\section{Introduction}

Livestock production constitutes a very important component of the agricultural economy of developing countries including Sudan, a contribution that goes beyond direct food production to include multipurpose uses, such as skins, fiber, fertilizer and fuel, as well as capital accumulation (Sansoucy, 1995). According to the author livestock are closely linked to the social and cultural lives of several million resource-poor farmers for whom animal ownership ensures varying degrees of sustainable farming and economic stability. Hence animal production is the most important economic activity in rural areas of Sudan where nearly $67 \%$ of the villagers and some urban communities are involved in activities related to livestock production services (El Hag et al., 2001). North Kordofan States is among most livestock populated areas of the Sudan. It is the homeland of camels in the northern arid and semiarid zones, cattle in savannah southern zone, goats and sheep in all ecological zones. The reputed Desert sheep with its ecotypes of Hamari and
Kabashi are raised in the State to supply domestic markets with live animals and meat. Most export sheep are taken from this area.

The livestock species in general and sheep in particular are reared by nomadic groups under different husbandry patterns on rangelands. The range areas are communally grazed without grazing management, improvement and rehabilitation interventions. The consequences of communal grazing are many the most obvious one being change of plant composition where palatable species are replaced by less acceptable or even harmful ones. Recently there have been increasing reports of incidence of phytobezoars in sheep on rangelands of the Western part of North Kordofan State. Empirical observations and reports from workers and farmers have indicated that grazing on areas with Ipomea spp might have been a possible cause for the disorder (Jadalla and Mekki, 2012). A comprehensive study was proposed to investigate cause (s), mode of formation and degree of the incidence (Jadalla, 2007). A preliminary study was 
conducted to elucidate which Ipomea spp was responsible for the phytobezoars formation in sheep and it was found that Merrimia emarginata initiated formation of phytobezoars (Jadalla and Mekki, 2012). Stage of growth and level of intake that could cause the incidence were not investigated.

\section{The Objective of the Study}

The overall objective of the study is to contribute towards alleviating problems that constrain development of sustainable livestock production patterns depending on the vast rangelands as main feed source in Kordofan. Specifically this study was proposed to investigate the stage of maturity of Ipomea species responsible for initiating the incidence of phytobezoars in sheep.

\section{Materials and Methods}

The Study Area

This study was conductedin Western part of North Kordofan State,Sudan. The State mostlylies within arid and semiarid agro-climatic zones, an annual rainfall ranges from $0-75 \mathrm{~mm}$ in the north and $500 \mathrm{~mm}$ in the south. Thedominant over storey vegetation is Acaciatortilis, Acacia senegal, Balanites aegyptiaca, Adansonia digitata, Cadabafarinose, Acacia nubica and Acacia nilotica. The dominant under storey vegetation is Cenchus bilforus, Alysicarpus moniferaand Ipomea spp (Khatir and Jadalla, 2014).

The state of North Kordofan (now North and part of west Kordofan) lies in the dry zone in central Sudan between latitudes $15^{\circ}-11^{\prime}$ and $45^{\circ}-16$ 'north and longitudes $27^{\circ} .15^{\prime}-32^{\circ}$ east. It is bordered by six states: Northern State from the north, Khartoum State and White Nile from the east, South Kordofan in the south, South Darfur from the south-west and North Darfur in the west. North Kordofan State at time of the study covered an area of 244.700 square $\mathrm{km}$ meters, equivalent to 139 square miles and 58.8 million acres of land, the state is divided into four groups: land of Al gayzan, sandy, Garduod sediment or loamy sand, valleys and cracking clay soil. It is largely an undulating plain, with the Nuba Mountains in the southeast quarter. During the rainy season from June to September, the area is fertile, but in the dryseason, it is virtually deserted with an estimated population according to the census in 2008 as 2.920 .992 persons distributed among the various localities, characterized by heterogeneous population according to geographical diversity, environmental, lifestyle, rural and urban residents and immigrants (Maruod et al., 2014; RPA, 1993).

\section{The Experimental Animals and Treatments}

Thirty castrated rams of Deserts sheep, subtype Hamari at the age 1.5-2 years were used in this study. The animals were divided into five similar groups each with six animals. They were ear-tagged to facilitated identification during treatments. The animals were vaccinated against the diseases endemic in the study area. A broad spectrum anthelmentic was used for treatment against internal and external parasites. The animals were individually penned with feeding and drinking troughs. Prior to commencement of the treatments, the rams were weighed and one every week to the end of the trial period of ninety days. The animals were diagnosed before the trial for phytobezoars and once a week by palpation. At the end the animals were slaughtered to confirm presence of phytobezoars, site of formation and their physical and chemical characteristics.

\section{The Experimental Feed}

Chemical composition of plant material at three maturity stages is presented in Table 1. Experimental rations were formulated to meet the requirements of the rams at the weight indicated. The chemical composition and $\%$ ingredients included in the rations used in the trial are presented in Table 2. The nutritive value of the rations with different levels of $M$ emarginata is presented in Table 3. The experimental groups were fed a basal diet of Eragrostis tremula (Bino) grass ad libitum and were supplemented with rations containing graded levels of Merrimia emarginata; atvegetative before flowering stage (Ration, II), at flowering stage (Ration III), with immature pods (Ration IV) and at full maturity stage (Ration V). Ration I was formulated without Merrimia emarginatabiomass.

\section{Chemical Analysis}

Samples of $M$ emarginata at different stages of maturity, biomass samples from Eragrostis tremula (Bino) grass, feed ingredients used in formulating the experimental rations and the phytobezoars removed from different parts of the digestive tract were all analyzed via proximate analysis according to the procedures described by AOAC (2000). In vitro dry matter and organic matter digestibility was determined according to the methods described by Telly and Terrie (1963). Forage fiber analysis method was used for determining fiber type of the phytobezoars retained.

Table 1 Chemical composition of Merrimia emarginata at four stages of maturityand natural grazing grass

\begin{tabular}{l|ccccccc}
\hline \multicolumn{1}{c|}{ Stage of maturity } & DM & OM & CP & CF & NFE & EE & ASH \\
\hline Before flowering & $91.25^{\mathrm{D}}$ & $79.43^{\mathrm{B}}$ & $6.11^{\mathrm{C}}$ & $18.12^{\mathrm{D}}$ & $52.51^{\mathrm{A}}$ & $2.92^{\mathrm{B}}$ & $11.62^{\mathrm{B}}$ \\
At flowering & $93.21^{\mathrm{C}}$ & $84.42^{\mathrm{A}}$ & $6.42^{\mathrm{C}}$ & $21.31^{\mathrm{C}}$ & $48.63^{\mathrm{C}}$ & $2.84^{\mathrm{B}}$ & $7.94^{\mathrm{C}}$ \\
With immature pods & $93.21^{\mathrm{B}}$ & $77.23^{\mathrm{C}}$ & $7.11^{\mathrm{B}}$ & $22.62^{\mathrm{B}}$ & $49.35^{\mathrm{B}}$ & $3.52^{\mathrm{A}}$ & $15.63^{\mathrm{A}}$ \\
At full maturity & $95.81^{\mathrm{A}}$ & $84.32^{\mathrm{A}}$ & $8.51^{\mathrm{A}}$ & $24.61^{\mathrm{A}}$ & $49.24^{\mathrm{B}}$ & $3.91^{\mathrm{A}}$ & $11.65^{\mathrm{B}}$ \\
Eragrostis tremula (Bino) & 94.32 & 88.21 & 5.46 & 21.35 & 53.90 & 11.5 & 11.46 \\
\hline
\end{tabular}

Values within the same column bearing different superscripts $(\mathrm{A}, \mathrm{B}, \mathrm{C}$ and $\mathrm{D})$ differ significantly $(\mathrm{P}<0.01), \mathrm{DM}=\mathrm{dry}$ matter, OM=organic matter, $\mathrm{CP}=$ crude protein, $\mathrm{CF}=$ crude fiber, $\mathrm{NFE}=$ nitrogen free extract, $\mathrm{EE}=$ ether extract 
Table 2 The chemical composition and $\%$ of ingredients included in the rations used in the trial

\begin{tabular}{l|cccccccc}
\multicolumn{1}{c|}{ Feed } & $\%$ & DM & OM & C P & CF & NFE & EE & Ash \\
\hline Merrimia emarginata(late mature) & & 95.8 & 84.2 & 8.5 & 24.6 & 49.2 & 3.9 & 11.6 \\
Sorghum & 30 & 94.5 & 91.85 & 13.23 & 2.48 & 78.44 & 2.5 & 2.15 \\
Groundnut seed cake & 20 & 95.4 & 85.15 & 43.58 & 9.72 & 24.89 & 7.96 & 9.25 \\
Groundnut bran & 45 & 59.00 & 50.48 & 9.71 & 26.6 & 15.00 & 6.18 & 8.52 \\
Oyster & 2 & & .000 & 0.00 & 0.00 & 0.00 & 0.00 & \\
Common salt & 3 & & 0.00 & 0.00 & 0.00 & 0.00 & 0.00 & 3.46 \\
Ration used in the trial & & 87.29 & 77.30 & 17.05 & 14.68 & 45.26 & \\
\hline
\end{tabular}

DM-dry matter, OM-organic matter, CP- crude protein, CF-crude fiber, NFE-nitrogen free extract, EE-ether extract

Table 3 Chemical composition of the phytobezoars as affected by the site of formation with in the digestive tract

\begin{tabular}{l|ccccccccc}
\hline \multicolumn{1}{c|}{ Site in the gut } & DM & OM & CP & CF & EE & NFE & ASH & NDF & ADF \\
\hline Rumen & $89.32^{\mathrm{A}}$ & $78.56^{\mathrm{A}}$ & $5.23^{\mathrm{B}}$ & $30.55^{\mathrm{A}}$ & 1.03 & $34^{\mathrm{C}}$ & $11^{\mathrm{A}}$ & $67^{\mathrm{A}}$ & $34^{\mathrm{A}}$ \\
Reticulum & $87.21^{\mathrm{A}}$ & $78.13^{\mathrm{A}}$ & $7.12^{\mathrm{A}}$ & $25.53^{\mathrm{B}}$ & 1.12 & $37^{\mathrm{B}}$ & $9^{\mathrm{B}}$ & $54^{\mathrm{B}}$ & $31^{\mathrm{B}}$ \\
Omasum & $81.39^{\mathrm{B}}$ & $75.23^{\mathrm{B}}$ & $7.56^{\mathrm{A}}$ & $21.45^{\mathrm{C}}$ & 1.01 & $46^{\mathrm{A}}$ & $6^{\mathrm{C}}$ & $55^{\mathrm{B}}$ & $32^{\mathrm{B}}$ \\
\hline
\end{tabular}

Values within the same column bearing different superscripts $(\mathrm{A}, \mathrm{B}, \mathrm{C}$ and $\mathrm{D})$ differ significantly $(\mathrm{P}<0.01)$, DM=dry matter, OM=organic matter, $\mathrm{CP}=$ crude protein, $\mathrm{CF}=$ crude fiber, $\mathrm{NFE}=$ nitrogen free extract, $\mathrm{EE}=$ ether extract

Table 4 The effects of feeding sheep with Merremia emarginata at different stages of maturity on dry matter intake, live weight change and feed conversion ratio treatment

\begin{tabular}{l|ccccc}
\hline \multicolumn{1}{c}{ Parameters studied } & I & II & III & IV & V \\
\hline No of animals & 6 & 6 & 6 & 6 & 6 \\
Experiment period / days & 61 & 61 & 61 & 61 & 61 \\
Initial weight (Kgs) & 31.94 & 32.09 & 31.48 & 31.30 & 31.38 \\
final Weight (Kgs) & $35.41^{\mathrm{A}}$ & $35.75^{\mathrm{A}}$ & $43.11^{\mathrm{B}}$ & $25.87^{\mathrm{C}}$ & $25.79^{\mathrm{C}}$ \\
dry matter intake g/day & $828^{\mathrm{A}}$ & $834^{\mathrm{A}}$ & $802^{\mathrm{B}}$ & $676^{\mathrm{C}}$ & $532^{\mathrm{D}}$ \\
Live weight change g/day & $56.86^{\mathrm{A}}$ & $51.5^{\mathrm{A}}$ & $41.11^{\mathrm{B}}$ & $93.934^{\mathrm{C}}$ & $91.639^{\mathrm{C}}$ \\
Feed conversion ration & 14.562 & 16.194 & 19.508 & $3^{\mathrm{B}}$ & $\overline{5^{\mathrm{A}}}$ \\
No of balls/ sheep & 0 & 0 & 0 & $3^{\mathrm{B}}$ & \\
\hline
\end{tabular}

Means with different superscripts (A, B, C and D) on the same row are different significantly (P<0.01), I-control (Eragrostis tremula at dough stage), II-Merrimia emarginata before flowering, III - at flowering stage, IV- with immature pods and V-fully mature

\section{Statistical Analysis}

The design of the experiment on chemical analysis of M. emarginata, the feeding trial and phytobezoars chemical composition as affected by the site of formation was completely randomized design according to Steele and Torrie (1997). Analysis of variance was done according to Snecedor and Cochran (1982). Means were compared for significance of their differences according to Duncan multiple range test.

\section{Results and Discussion}

Chemical composition of the plant material at different stages is presented in Table 1. Crude protein, crude fiber and ether extract increased with advancement of the stage of maturity unlike nitrogen free extract that decreased from 52.51 when the plant was harvested at pre-flowering stage to 49.24 when it reached full maturity. Ash content was the lowest at flowering stage (7.94) and the highest for plant biomass with immature pods. The decreased amounts of NFE could be attributed to lignifications of the plant with advanced stages of maturity. The nutrients content of the biomass at early stages of maturity is comparable with values reported for common fodder crops grown in Sudan as reported by Abuswar (2007). It is also found that fiber content increased significantly with advancement of stage of maturity.
Effects of Feeding Merremia Emarginata at Four Maturity Stages on Sheep Performance

Dry matter intake, DMI, of sheep on rations containingMerrimia emarginata at different stages of maturity is presented in Table 4. The dry matter intake, DMI, of sheep deceased significantly $(\mathrm{P}<0.01)$ with the full mature and when the plant had immature pods. A significant $(\mathrm{P}<0.01)$ decrease of VDMI of sheep at the flowering stage compared to control and the flowering stage was also detected. The increased feed intake at early stages of maturity might be due to low fiber content and higher protein level that might have enhanced digestibility hence feed intake. Similar results were reported by Jadalla (1995) and Mohamed Ali (2002) who showed that good quality such as groundnut haulms might lead to increased low quality intake of sheep.

The live body weight changes of sheep on the experimental feed is also presented in Table 4 and illustrated in Figure 1. The body weight change of sheep followed the same trend observed in feed intake. Significant $(\mathrm{P}<0.01)$ decrease in the final body weight was observed in sheep on both the last two stages of maturation of the plant although the animals offered Merrimia emarginata at the flowering stage showed the highest $(\mathrm{P}<0.01)$ body weight gain. Feed conversion ratio was best with the control ration, the natural grazing and the concentrate free of the plant biomass under study 
followed by the animals on a ration with $M$. emarginata before flowering and at flowering stage while negative values were obtained from animals on rations containing plant biomass with immature pods and plant material at late maturity stage Table 4 . The increased body weight gains might be attributed to increased intake and nutrients digestibility at early stages of maturity. Decreased intake was expected since presence of phytobezoars upon taking plant biomass at flowering seed formation and late maturity stages. Digestibility coefficients of the feed were also low leading to limited nutrients intake impairing animal growth. The results reported here are comparable with those reported by Jadalla and Bukhari (2014) who found that sheep consuming low quality roughage material without proper supplementation could not be able to gain weight.

In vitro dry matter and organic matter digestibility coefficients showed that lower nutrients digestibility coefficients were obtained in rations with higher crude fiber content and higher digestibility coefficients were associated with lower crude fiber content.

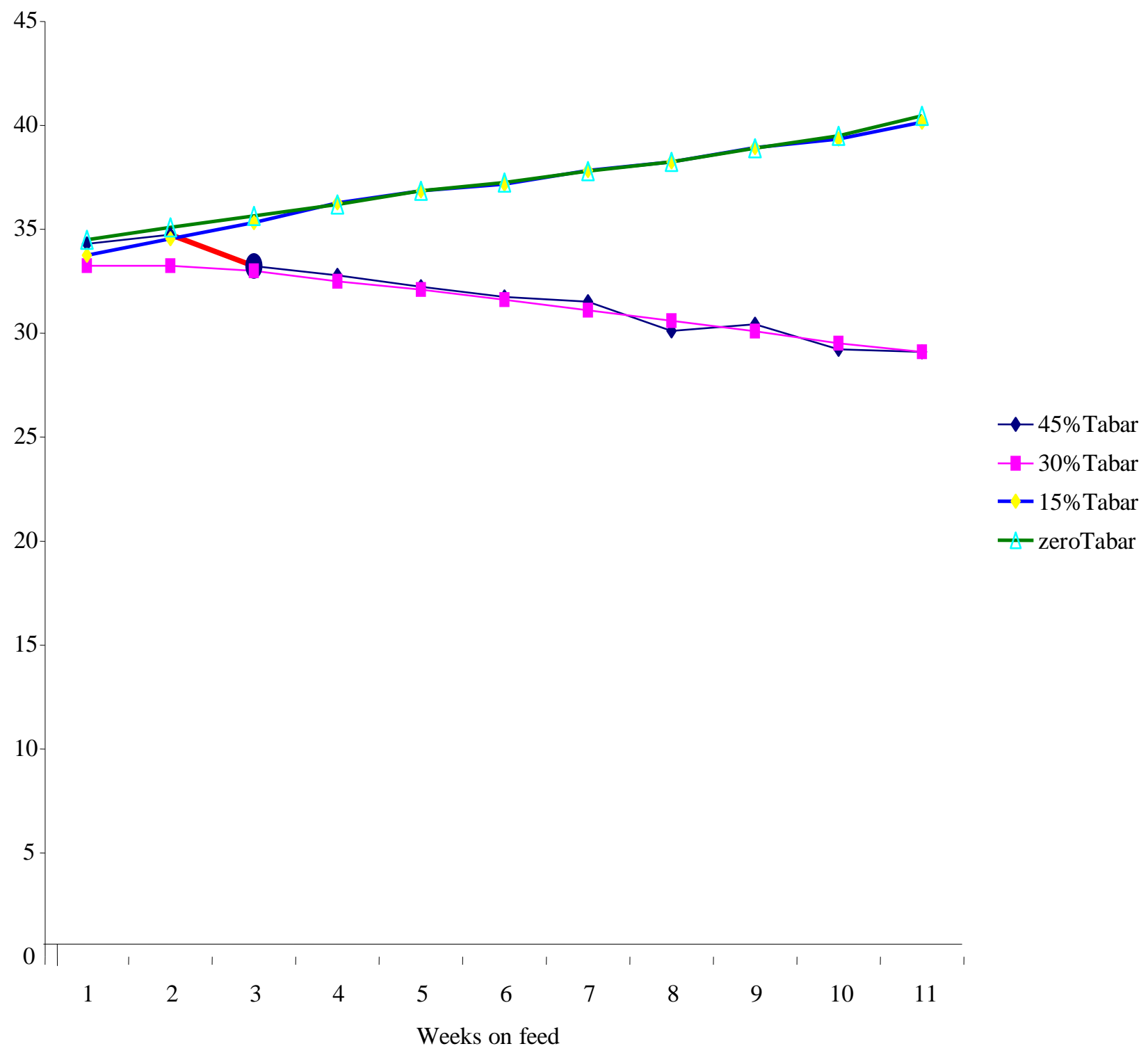

Figure 1 Effects of feeding different levels of Tabar on live body weight change in sheep 


\section{References}

Abuswar AH. 2007. Alternative paradigms and implication for development. J. Range Mange. 41 (6):450-450.

AOAC. 2002. Association of Official Analytical Chemists The official Methods of analysis, 16th ed, Washington DC

El-Hag FM, Fadlalla B, Mukhrar HK. 2001. Some production characteristics of Sudanese Desert sheep under range condition in North Kordofan, Sudan. rop. Anim. Heal and Prod. 33: 229-239

Jadalla JB, Mekki DM. 2012. The Incidence and Characteristics of Phytobezoars in Sheep Slaughtered at Some Abattoirs in Kordofan, Sudan J Anim Prod Adv. 2(9): 389-397

Jadalla JB. 1995. Effects of supplementation of the dry season Grazing with groundnut haulms on Feed intake Nutrient digestibility and sheep performance in North Kordofan, Sudan. M Sc thesis, Faculty of Animal Production, University of Khartoum, Sudan.

Jadalla JB. 2007. Investigation into the Causes and Degree of Incidence of the ball Shaped Bodies (Daradim) in Sheep on Rangelands of West Kordofan States Sudan Ph D thesis, University of Kordofan, Sudan

Khatir AA, Jadalla JB. 2014. Assessment of rangelands biomass using Remote Sensing and Geographical Information System (GIS) in Kordofan, Sudan. University of Kordofan Journal of Natural Resources and Environmental Studies, UKJNRES, 1(1): 60-70
Mohamed Ali MA. 2002. Body measurements, performance and meat characteristics of Sudan Desert sheep. Ph D. Thesis, University of Gezira, Sudan

RPA. 1993. Range and Pasture Administration. Range and Pasture Administration Annual report. Ministry of agriculture and animal wealth North Kordofan (Sudan)

Sansourcy S. 1995. Livestock - a driving force for food security and sustainable development http://www.fao.org/ docrep/v8180t/v8180T07.htm

Snedecor GW, Cochran WG. 1980. Statistical Methods. Seventh Edition. ISBN,0813815606Hardcover - 1980

Steel RG, Torrie JH, Dickey DA, PH.D. 1997. Principles and Procedures of Statistics Published by McGraw-Hill Companies.

Tilley JMA, Terry RA. 1963. A two-stage technique for the in vitro digestion of forage crops. J. Brit. Grassland Soc. 18:104-11, 1963. 